\title{
ISOTOPIC FRACTIONATION AT THE BASE OF POLAR AND SUB-POLAR GLACIERS
}

\author{
By G.S. BOULTON* \\ (School of Environmental Sciences, University of East Anglia, Norwich NR4 7TJ, England, and Fysisch \\ Geografisch en Bodemkundig Laboratorium, University of Amsterdam, Amsterdam, Holland) \\ and U. SPRING \\ (Electrowatt, CH-8022 Zürich, Switzerland)
}

\begin{abstract}
The melting of ice and the subsequent production of regelation ice from the melt water in a largescale closed system beneath sub-polar and polar glaciers produces progressive fractionation between the melt water and the regelation ice derived from it. A theory is developed which predicts the change of isotopic composition in regelation ice in a subglacial zone of freezing and in the water from which it is derived. The theory is tested against data from the Byrd Station bore hole in West Antarctica, and applied to explain features of the isotopic composition in several other glaciers where thick sequences of regelation ice have formed.
\end{abstract}

The principal conclusions are:

1. Basal isotopic profiles can be used to reconstruct important features of a glacier's hydrological system.

2. Isotopic profiles in basal regelation ice do not simply reflect isotopic characteristics of ancient atmospheres but also, by using the theory, some of the isotopic characteristics of the normal glacier ice which was destroyed by melting and subsequently produced regelation ice can be reconstructed. Basal regelation ice at Byrd Station reflects an original ice source isotopically colder than the overlying normal ice, and may have formed during the penultimate glacial period, equivalent to stage 6 of the oceanic record.

3. The subglacially derived debris typically found in basal regelation ice gives a complex strain response to a changing pattern of stresses produced by flow over an irregular subjacent bed. Thus, complex tectonic structures in this ice produce highly variable isotopic profiles. However, its gross isotopic characteristics can still be used to reconstruct some of its history. A sharp change in isotopic values tends to occur at the upper limit of basal regelation ice, the nature of which depends on the style and thickness of tectonic disturbance.

4. Isotopic profiles in basal ice can be used to distinguish normal glacier ice from regelation ice, and give strong support to the view that regelation is the major process by which debris is incorporated into the base of a glacier.

RÉsumé. Une théorie sur le fractionnement isotopique à la base de glaciers polaires et sub-polaires. L'alternance de fonte et regel à grande échelle à la base de glaciers polaires et sub-polaires produit un fractionnement progressif entre l'eau de fusion et la glace regelée qui suit. Une théorie est développée pour prévoir le changement de la composition isotopique lors du regel dans une zone sous glaciaire. La

*Present address: Grant Institute of Geology, University of Edinburgh, Edinburgh EH9 3JW, Scotland. théorie est testée sur les données du forage Byrd, Antarctique de l'ouest, et appliquée pour expliquer des caractéristiques de la composition isotopique dans plusieurs autres glaciers où d'épaisses séquences de glace de regel se sont formées.

Les conclusions principales sont:

1. Des profils isotopiques à la base peuvent être utilisés pour reconstituer les caractéristiques importantes d'un système hydrologique glaciaire.

2. Des profils isotopiques sur des glaces de regel à la base ne reflètent pas de façon simple les caractéristiques des atmosphères passées mais, à l'aide de la théorie, une partie des carctéristiques isotopiques de la glace normale avant destruction par fonte et regel peut être reconstituée. La glace formée par regel à la base à la station Byrd reflète une origine particulière plus froide que la glace normale qui la recouvre et peut avoir été formée au cours de l'avant dernière période glaciaire, correspondant au stade 6 de l'enregistrement océanique.

3. Les débris sous-glaciaires typiques trouvés dans la glace de regel produisent une réponse complexe en déformation à un état de contrainte produit par l'écoulement sur un lit irrégulier. C'est pourquoi les structures tectoniques complexes de cette glace conduisent à des profils isotopiques hautement variables. Néanmoins ses caractéristiques globales peuvent encore être utilisées pour reconstituer une partie de son histoire. Un changement brusque des valeurs isotopiques se produit à la limite supérieure de la glace basale de regel, dont la nature dépend du genre et de l'épaisseur de la perturbation tectonique.

4. Des profils isotopiques de glace basale peuvent être utilisés pour distinguer la glace normale de celle de regel et apporter un support solide au point de vue selon lequel le regel est la mode majeur d'incorporation de débris à la base d'un glacier.

ZUSAMMENFASSUNG. Isotopenfraktionierung am Untergrund polarer und subpolarer Gletscher. Das Schmelzen von Eis und das darauffolgende Wiedergefrieren des Schmelzwassers in einem grossräumigen, geschlossenen System unter subpolaren und polaren Gletschern erzeugt eine fortschreitende Fraktionierung zwischen dem Schmelzwasser und dem daraus wiedergefrorenen Eis. Es wird eine Theorie aufgestellt, die den Wandel der Isotopenzusammensetzung des wiedergefrorenen Eises in einer subglazialen Gefrierzone und des davon herstammenden Wassers vorhersagt. Die Theorie wird mit Daten aus dem Bohrloch der Byrd-Station in West-Antarktika geprüft und zur Erklärung von Erscheinungen in der Isotopenzusarnmensetzung bei einigen anderen Gletschern mit dicken Lagen wiedergefrorenen Eises herangezogen.

Die wichtigsten Schlussfolgerungen sind: 
1. Isotopenprofile am Untergrund können zur Rekonstruktion wichtiger Erscheinungen im hydrologischen System eines Gletschers benutzt werden.

2. Isotopenprofile in wiedergefrorenem Eis am Untergrund spiegeln nicht einfach die Isotopencharakteristiken früherer Atmosphären wider; aus der Theorie folgt vielmehr, dass einige der Isotopencharakteristiken des normalen Gletschereises, das durch Schmelzen aufgelöst wurde und sich in der Folge zu wiedergefrorenem Eis umwandelte, rekonstruiert werden können. Wiedergefrorenes Eis am Untergrund der Byrd-Station spiegelt eine ursprüngliche Eisquelle wider, die isotopisch kälter als das darüberliegende normale Eis ist und sich während der vorletzten Vereisungsperiode, entsprechend dem Stadium 6 der ozeanischen Reihe, gebildet haben mag.

3. Der vom Untergrund stammende Schutt, der für wieder-

\section{INTRODUCTION}

The stable isotope composition of ice in glaciers is determined by primary climatic processes which determine the character of precipitation on their surfaces, and by subsequent diagenetic and metamorphic processes which may lead to movement and fractionation of isotopes within the ice mass.

Most work on stable isotopes in glaciology has been concerned with the reconstruction of changing climatic conditions on the surface of ice sheets and glaciers from studies of isotopic variations in bore-hole cores. Because of the possible isotopic complications which might be produced in the basal parts of ice sheets, workers have been reluctant to use basal isotopic profiles as direct indicators of climatic change (Paterson and others, 1977; Gow and others, 1979).

We wish to present a simple theory of isotopic evolution at the base of a glacier, predicting a pattern of expectations which enable us to use basal isotopic profiles as indicators of basal processes, and which can, in certain cases, be used to isolate that component of the isotopic record which reflects an original climatic signal.

We suggest two fundamental controls on the isotopic patterns produced in basal ice:

(a) Whether there is net freezing-on of regelation ice at the glacier sole (basal accumulation) or net melting of the glacier sole but with a basal regelation layer which is continually destroyed and re-formed (basal ablation).

(b) The origin and flow path of water at the glacier sole: whether surface water reaches the bed; whether water drains away from the glacier sole and with what frequency; and whether there is a large- or small-scale closed system of water flow at the glacier sole.

ISOTOPIC FRACTIONATION AT THE BASE OF POLAR GLACIERS WHERE THERE IS NET FREEZING-ON OF REGELATION ICE

It is well known that fractionation of $\mathrm{D}$ and ${ }^{18} \mathrm{O}$ isotopes occurs during the freezing of water and the melting of ice. When ice is formed from an excess of water, there is an increase in the ${ }^{18} \mathrm{O} /{ }^{16} \mathrm{O}$ ratio in the ice compared with the original water reservoir, and a concomitant decrease in the ratio in the remaining water.

Lawson and Kulla (1978) developed the basis of a theory of isotopic fractionation from observations on Matanuska Glacier, where basal ice, presumed to be regelation ice, showed a different composition from that of overlying ice. Jouzel and Souchez (1982) have modelled the Rayleigh process for local fractionation between a solid and a liquid during regelation at the glacier sole. We have also modelled a Rayleigh process in order to analyse coupled large-scale spatial variations in the isotopic composition of basal regelation ice and the underlying melt water (cf Boulton, 1983). This theory can be used as a basis for gefrorenes Eis typisch ist, reagiert mit komplexen Deformationen auf ein wechselndes Spannungsfeld, das durch den Fluss über ein unregelmässiges Gletscherbett erzeugt wird. Deshalb haben komplexe tektonische Strukturen in diesem Eis ausserordentlich vielfältige Isotopenprofile zur Folge. Doch können die Isotopencharakteristiken dieses Eises im grossen immer noch teilweise zur Rekonstruktion seiner Vorgeschichte herangezogen werden. Häufig tritt ein scharfer Sprung in den Isotopenwerten an der Obergrenze des wiedergefrorenen Eises am Untergrund auf, dessen Natur von der Art und Dicke der tektonischen Störungen abhängt.

4. Höhenprofile im Eis am Untergrund können zur Unterscheidung zwischen normalem Gletschereis und wiedergefrorenem Eis dienen; sie sind ein starker Rückhalt für die Ansicht, dass Regelation der Hauptprozess bei der Aufnahme von Schutt am Untergrund eines Gletschers ist.

reconstructing the palaeohydrology of the subglacial system, and was first presented to the 1981 meeting of the British Branch of the International Glaciological Society.

Fractionation factors $(\alpha)$ between ice and water isotopes are defined by:

$$
\left({ }^{18} \mathrm{O}\right)=\frac{\left({ }^{18} \mathrm{O} /{ }^{16} \mathrm{O}\right) \text { ice }}{\left({ }^{18} \mathrm{O} /{ }^{16} \mathrm{O}\right) \text { water }}=\frac{R_{\text {ice }}}{R}
$$

where $R_{\text {ice }}$ and $R$ are the isotopic ratios of ice and water, respectively. O'Neill (1976) determined experimentally values of $\left({ }^{18} \mathrm{O}\right)=1.003$ and $(\mathrm{D})=1.019$.

We know that melt water can exist deep beneath modern ice sheets (Gow, 1970). Thermal modelling of ice sheets suggests that broad zones of melting and zones where the basal ice temperature is well below the melting point do occur, and further, theoretical and field studies suggest that melt water produced in zones of melting flows subglacially towards the glacier margin, and if it flows into a "cold zone" will freeze to the glacier zone as regelation ice (Weertman, 1961; Boulton, 1972; Gow and others, 1979).

Figure 1 is an idealized ice sheet with a central zone $\mathrm{A}-\mathrm{B}$ in which temperatures are below the melting point and no water is produced or consumed by freezing, and beneath which there is thus no water flow although we assume pores and voids to be water-saturated; a zone $\mathrm{B}-\mathrm{C}$ in which water is produced by melting and which flows outwards to balance the melting rate in order to allow a steady state; a zone $C-D$ in which the rate of heat conduction through the ice sheet exceeds the rate of basal frictional heating and the geothermal heat flux, and thus has a capacity to freeze water from the subglacial reservoir, until all the water produced in zone $\mathrm{B}-\mathrm{C}$ has been frozen on (point $\mathrm{D}$ ); a zone $D-E$ which the prior exhaustion of the water input from B-C excludes an external heat source, the glacier/bed interface is again frozen and there is no subglacial water movement.

In zone $\mathrm{A}-\mathrm{B}$, the basal ice carries an isotopic record which reflects surface climate; in zone $B-C$, some of this basal ice is destroyed; in zone $C-D$, fresh regelation ice is produced, and in zone $\mathrm{D}-\mathrm{E}$ this new basal sequence is preserved. A further set of similar zones may occur downglacier.

We can be sure that the great thickness of ice along this profile will prevent any surface water finding its way to the glacier bed to disturb this system. Thus, the subglacial discharge of water $(Q)$ in the zone of melting $(\mathrm{B}-\mathrm{C})$ and the zone of freezing (C-D) can be calculated, as can the thickness of basal regelation ice in zone $\mathrm{C}-\mathrm{D}$.

Using a model such as this (Fig. 1), we can predict the nature of isotopic variation in basal regelation ice and subglacial water. We assume that subglacial flow of water in an aquifer of unspecified characteristics will cause mixing and homogenization of all subglacial melt water. Thus, at $c$ in Figure 1 we have a subglacial water discharge of $Q_{0}$ with a uniform isotopic ratio $R_{0}$. We assume that, because of the low permeability of basal ice compared with the 


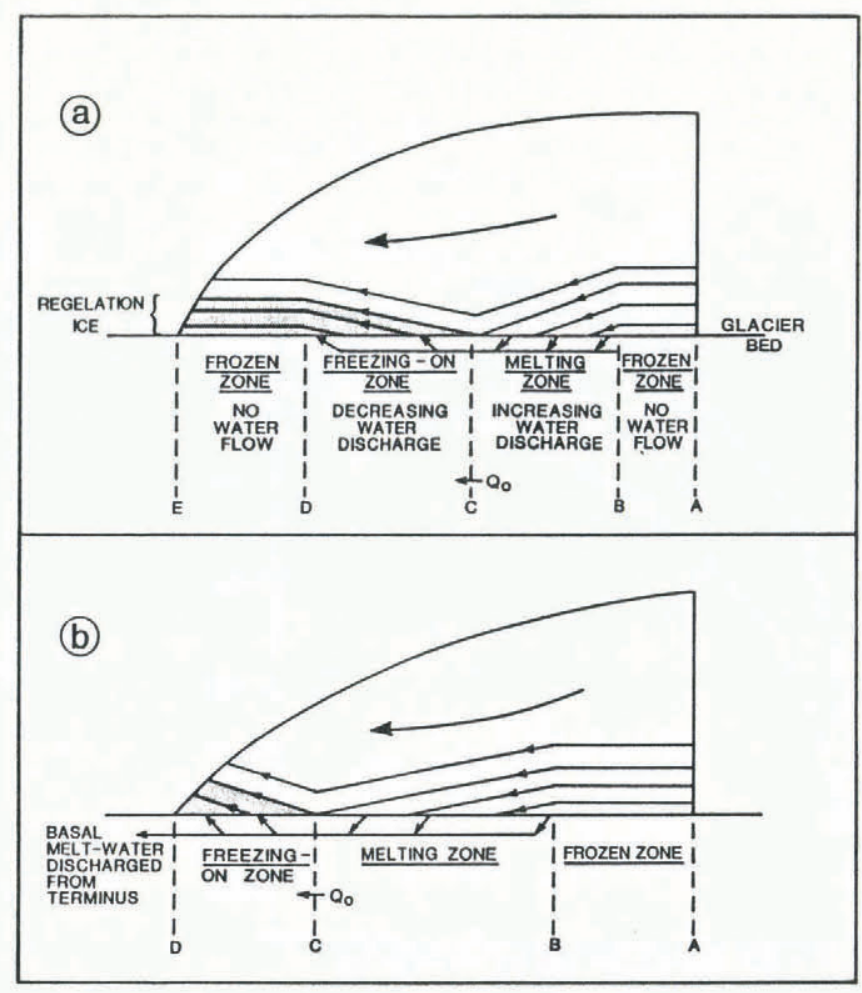

Fig. 1. An idealized ice sheet showing a complete sequence of possible basal mass-balance (melting or freezing-on) states. Beneath a given glacier we might find zones $\mathrm{AB}$ or $\mathrm{BC}$ only, or $\mathrm{AB}-\mathrm{BC}, \mathrm{AB}-\mathrm{CD}, \mathrm{BC}-\mathrm{CD}, \mathrm{BC}-\mathrm{DE}$, or a repetitive sequence if the bed is highly irregular (see Fig. 4).

melting rate, all the isotopic components of the ice will pass into the water reservoir when it melts, avoiding fractionation. Thus, $R_{0}$ is also the mean isotopic ratio of all the melted ice.

In the freezing zone C-D (Fig. 1), freezing will occur in the presence of excess water in which isotopic mobility will allow fractionation. As water discharge decreases in this zone due to freezing, the ratio of ${ }^{18} \mathrm{O}$ and $\mathrm{D}$ will also decrease because of the relative enrichment of regelation ice in these isotopes.

Let $N$ denote the number of heavy isotopes and $M$ the number of light isotopes, respectively, within the basal water discharge $(Q)$ at position $x$. Then the isotopic ratio is:

$$
R_{(x)}=N / M
$$

Supposing a closed system, conservation of mass requires that the spatial change of $N, M$ within the basal water is balanced by the number of isotopes $(n, m)$ contained within the newly formed regelation ice:

$$
\frac{\mathrm{d} N}{\mathrm{~d} x}=n
$$

Hence the isotopic ratio of the regelation ice is:

$$
R_{\text {ice }}=n / m \text {. }
$$

Rewriting Equation (3) in terms of $M$ and $m$, taking into account Equations (2) and (4), leads to:

$$
(\alpha-1) \frac{1}{M} \frac{\mathrm{d} M}{\mathrm{~d} x}=\frac{1}{R} \frac{\mathrm{d} R}{\mathrm{~d} x},
$$

since $N \ll M, M$ can be set proportional to $Q$. Hence Equation (5) may be written in the form:

$$
(\alpha-1) \frac{1}{Q} \frac{\mathrm{d} Q}{\mathrm{~d} x}=\frac{1}{R} \frac{\mathrm{d} R}{\mathrm{~d} x} .
$$

Here, $\mathrm{d} Q / \mathrm{d} x$ denotes the freezing rate.

Integrating Equation (6) subject to the boundary values $Q_{0}$, the initial discharge at the beginning of the freezing zone (c, $x-0)$, and $R_{\text {ice }}$, its isotopic ratio, we obtain:

$$
\frac{R(x)}{R_{0}}=\frac{Q_{(x)^{\alpha-1}}}{Q_{0}} .
$$

$R_{0}$ is also the mean isotopic composition of all the ice melted in Bc. Given $R(x)$ from Equation (7), the isotopic concentration in regelation ice is determined by the fractionation factor, hence:

$$
R_{\text {ice }}=\alpha R \text {. }
$$

In Figure 2 we plot changing $\delta^{18} \mathrm{O}$ and $\delta D$ ratios in basal regelation ice and in the subglacial water reservoir which would occur in zone C-D of Figure 1, given the melting/freezing rate $(\mathrm{d} Q / \mathrm{d} x)$, and with $\alpha\left({ }^{18} \mathrm{O}\right)=1.003$, and $\alpha(D)=1.019$. The difference between isotopic concentrations of freshly formed basal regelation ice and immediately subjacent subglacial water at a given point will be:

$$
d_{1}=R_{\text {ice }}-R=R_{0}\left[Q / Q_{0}(\alpha-1)\right](\alpha-1)
$$

and the difference between the isotopic composition of subglacial water and $\mathrm{C}$ (mean of melted ice in $\mathrm{BC}$ ) and subglacial water at a given point will be:

$$
d_{2}=R_{0}-R=R_{0}\left[1-\left(Q / Q_{0}\right)\right]^{-1} .
$$

Standard water has a value of $8\left({ }^{18} \mathrm{O}\right)=-1.94^{0} / 00$ (Dansgaard and others, 1973). $\delta\left({ }^{18} \mathrm{O}\right)$ values in basal ice strongly depend on location and vary between $-10^{0} / 00$ and $-40^{\circ} \%$. Hence $K_{0}$ could vary from 0.990 to 0.960 , and the difference $d_{1}$ in Equation (6) is more or less independent of $K_{0}$.

To apply this theory to an actual glacier, we must know the freezing rate or discharge in the freezing zone, and have grounds for believing that the two basic assumptions of mixing of the subglacial water reservoir and no addition of surface water are true. Where we also have isotopic data, we can test these assumptions.

The theory is developed for a large-scale closed system where all the water produced in the zone of melting is used up as regelation ice in a freezing-on zone, beyond which there occurs a frozen zone where no more melt water is available, the glacier is frozen to its bed, a thick basal regelation zone of distinctive isotopic profile is preserved, and there is no subglacial water flow. However, it can also apply to a large-scale open system where the freezing-on zone extends to the glacier margin or is succeeded by a zone of melting, and melt water derived from the inner zone of melting escapes from the system (Fig. 1).

Figure 2 reflects an important general statement about the progressive fractionation of water and the regelation ice formed from it when water passes into a zone of freezing-on. It is a valuable basis for interpretation.

\section{TEST OF THE THEORY: THE BASAL ISOTOPIC PROFILE FROM BYRD STATION, ANTARCTICA}

Gow and others (1979) have presented a detailed isotopic profile from the basal part of the core taken from the $2164 \mathrm{~m}$ bore hole at Byrd Station on the West Antarctic ice sheet (Fig. 3a). Basally derived debris extends up to $4.83 \mathrm{~m}$ above the glacier sole, at which height entrapped air first appears in the core. This evidence led Gow and others (1979) to conclude that this basal $4.83 \mathrm{~m}$ of ice had been produced by freezing of subglacial melt water. 


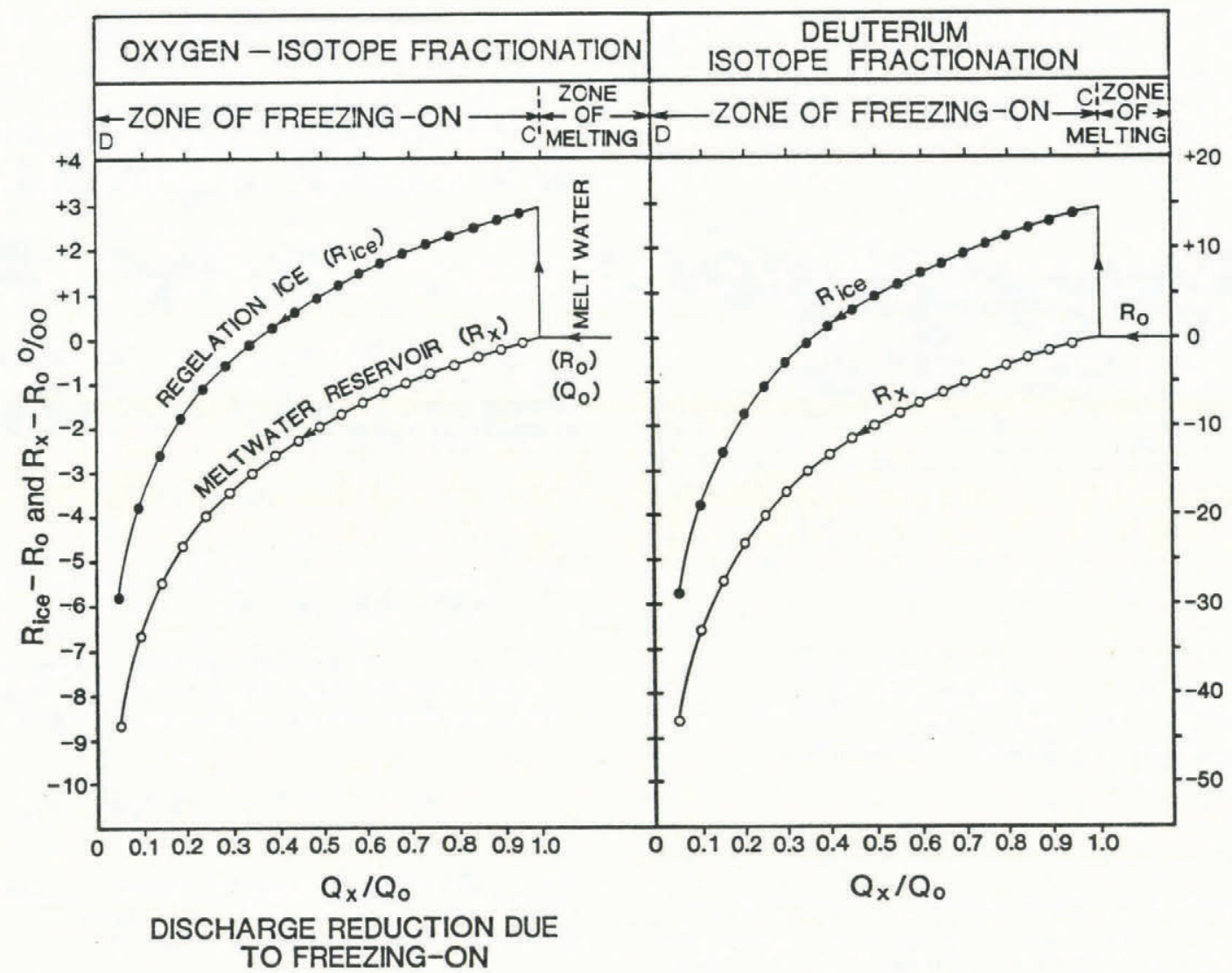

Fig. 2. Progressive fractionation of $\delta^{18} O$ and $\delta D$ in subglacial water $\left(R_{x}\right)$ and the overlying ice formed from it $\left(R_{\text {ice }}\right)$ when an initial subglacial water discharge $\left(Q_{0}\right)$ of isotopic composition $\left(R_{0}\right)$ from a zone of melting (Fig. 1, BC) is progressively frozen to the glacier sole in the succeeding zone (Fig. 1, CD) so that subglacial discharge $\left(Q_{x} / Q_{0}\right)$ diminishes.
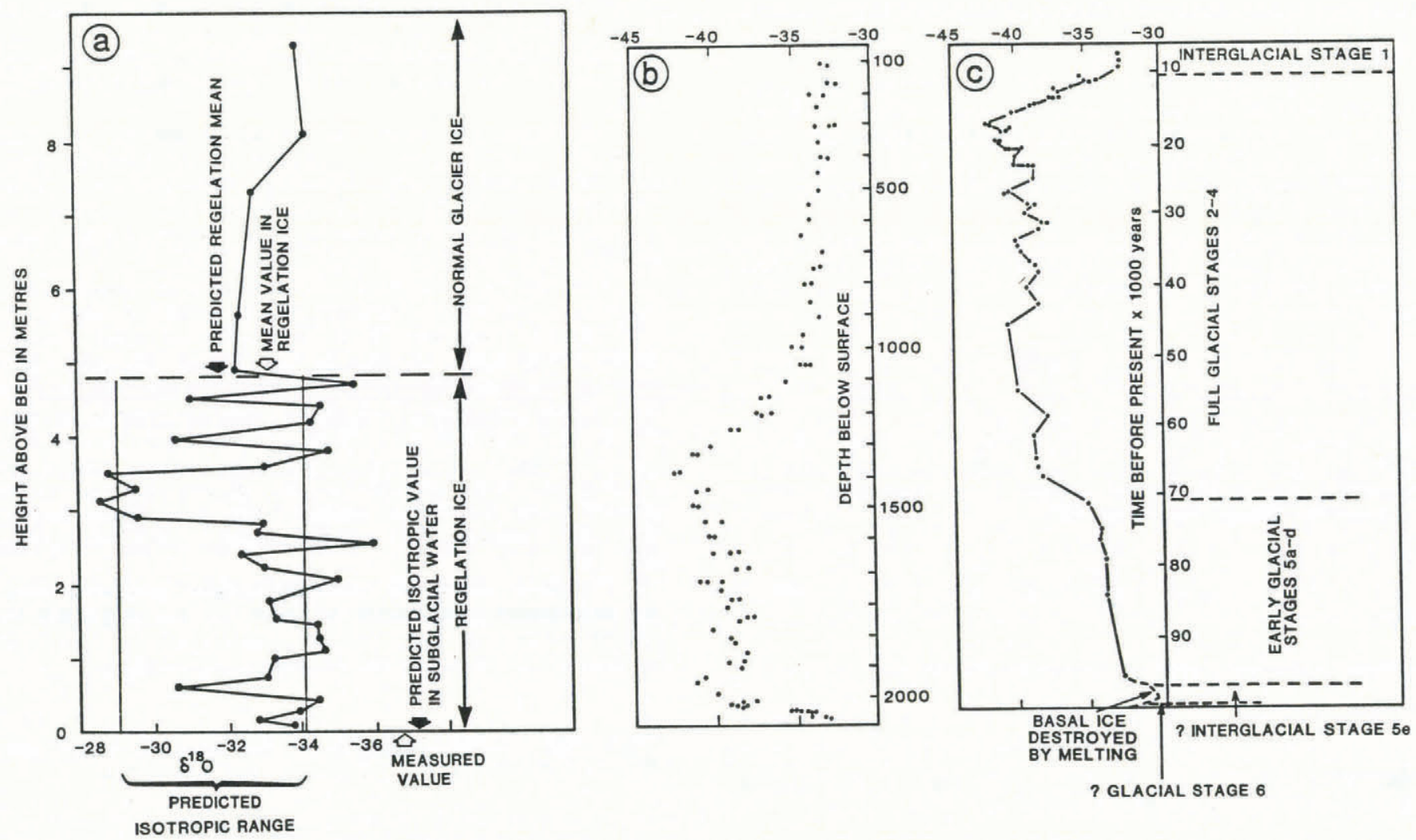

Fig. 3. Oxygen-isotope profile of the core taken from the Byrd Station bore hole, West Antarctica (data from Gow and others (1979), and Epstein and others (1970)).

(a) Isotopic composition of basal ice.

(b) Isotopic composition for the whole depth of the ice sheet.

(c) Isotopic composition against time, and with a correlation with the deep ocean isotopic stages. The ice deposited during stage 6 and part of stage $5 e$, the penultimate glacial and last interglacial stages, is suggested to have been destroyed by melting and re-formed as regelation ice. 
Boulton and Spring: Isotopic fractionation at the base of polar and sub-polar glaciers

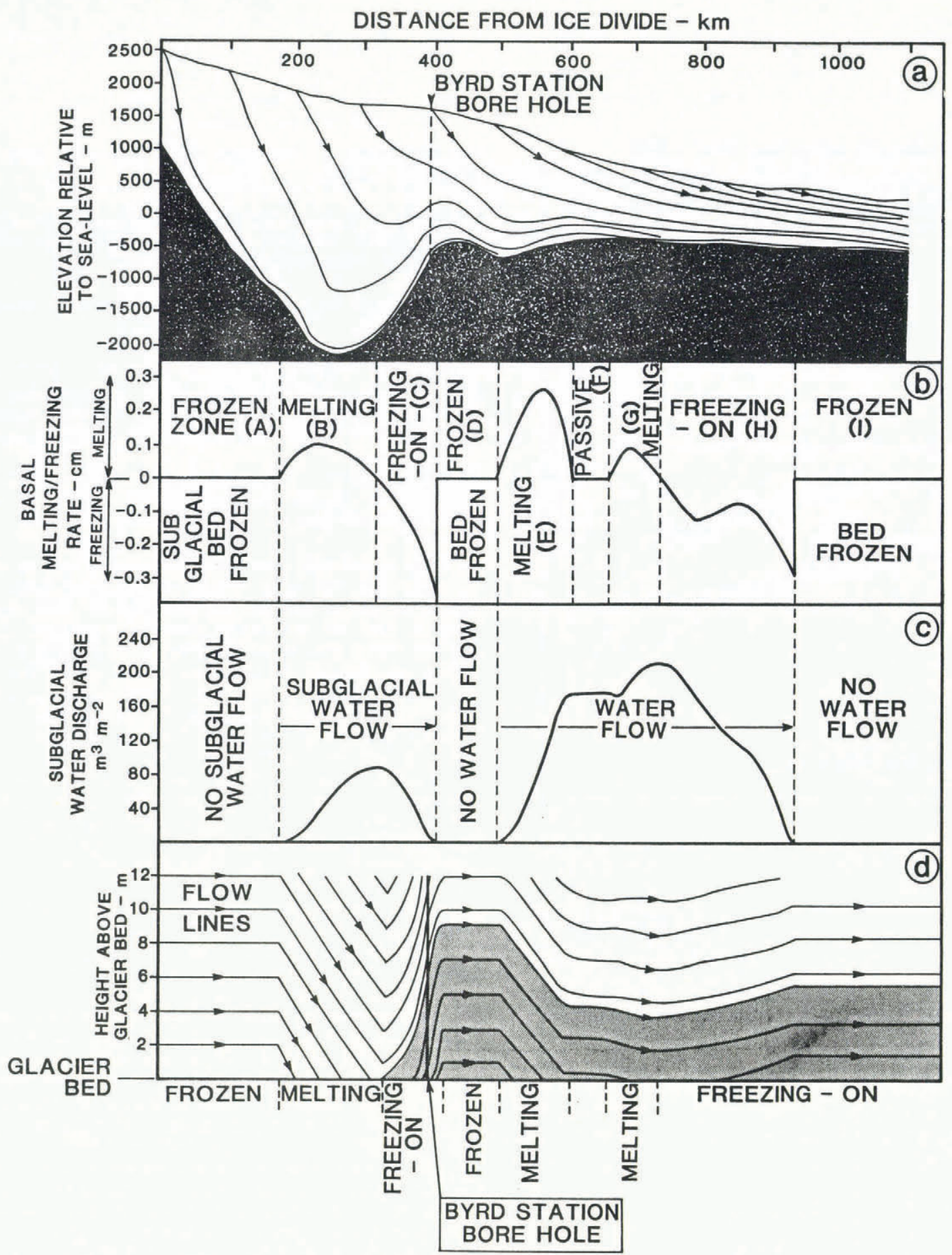

Fig. 4. A vertical section along a transect through Byrd Station, West Antarctica, showing patterns of basal melting, water flow, and regelation based on the modelling by Budd and others (1970).

(a) Flow lines along the transect and the location of the Byrd Station bore hole.

(b) The sequence of zones of melting, freezing-on, and frozen zones, and the rates of melting and freezing.

(c) Water discharges in zones of melting and freezing-on.

(d) Flow lines in relation to the bed. Flow lines descend to the bed in zones of melting (basal ablation) and rise from it in zones of freezing-on (basal accumulation). Regelation ice is stippled.

Using a thermal model, Budd and others (1970) computed the disposition of zones of melting and refreezing at the base of the ice sheet along a flow line through Byrd Station. They predicted the distribution of zones of melting and freezing-on, and the frozen zones shown in Figure 4a and b. A zone of net melting (B) up-glacier of Byrd Station is succeeded by a zone of freezing-on (C) near whose down-glacier extremity the Byrd Station bore hole was drilled. They predicted a thickness of $7 \mathrm{~m}$ of basal regelation ice at Byrd Station (Fig. 4d), which agrees well with the observed thickness of $4.83 \mathrm{~m}$.

Using Equations (7) and (8), and Budd and others' (1970) predicted values of subglacial water discharge (Fig. $4 c)$, the progressive fractionation in the zone of freezing-on (c, Fig. 4) of newly formed regelation ice and the subjacent water from which it is formed can be compared with the isotopic composition of the melt water at the down-glacier extremity of the melting zone (B). 
In order to reconstruct the theoretical isotopic profile through any vertical column of regelation ice in the freezing-on zone, we merely need to reconstruct flow paths within this zone and then to correlate each level within the

\section{Distance along flow line $-\mathrm{km}$}

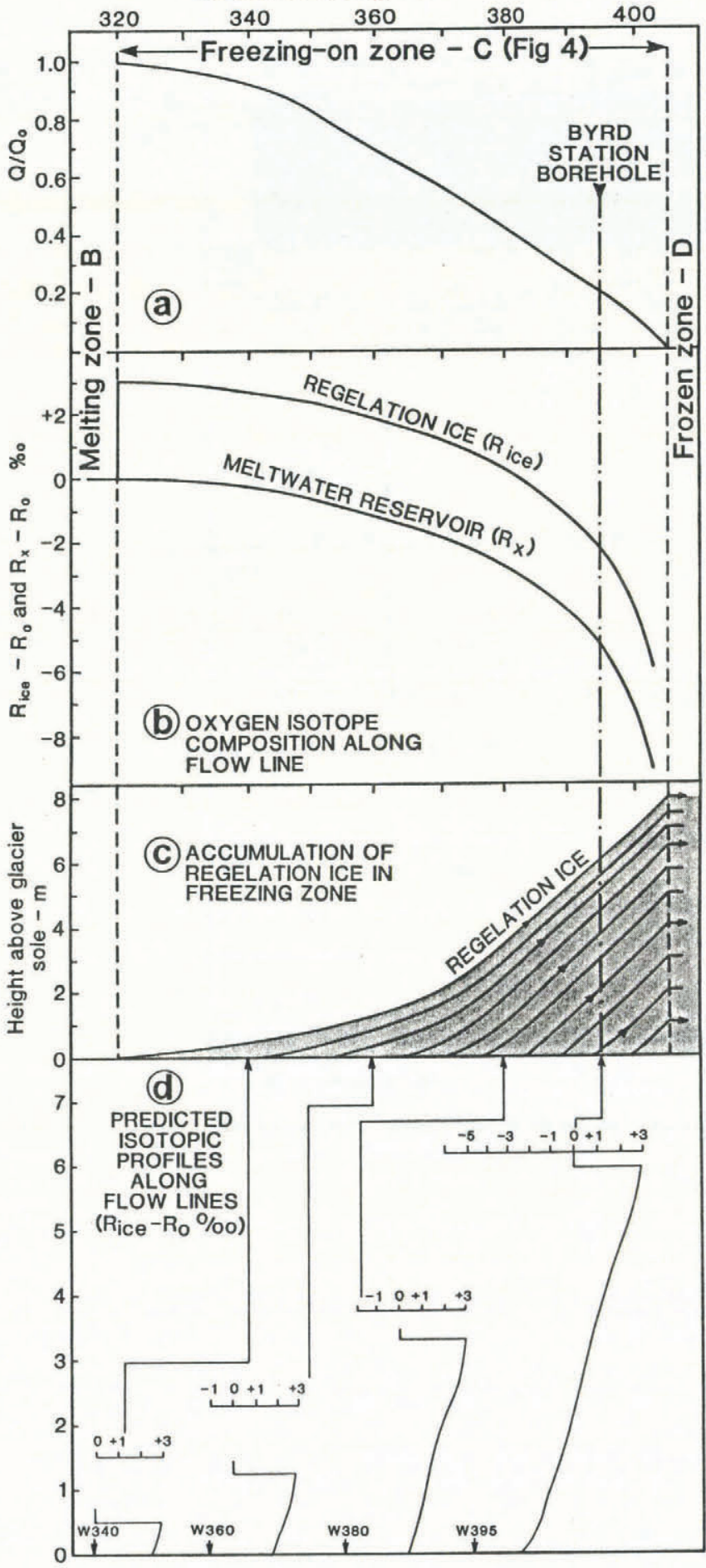

Fig. 5. Predicted oxygen-isotope fractionation patterns in freezing-on zone $\mathrm{c}$ along the Byrd Station transect.

(a) Reduction in subglacial water discharge.

(b) Progressive oxygen-isotope fractionation in newly formed regelation ice and the remaining subglacial water discharge.

(c) The build-up of basal regelation ice.

(d) Predicted deviation of $\delta^{18} O$ values from the values in parent ice in vertical profiles in basal regelation ice and relative values in subglacial water at different points along the transect $(340,360,380$, and $395 \mathrm{~km})$. This assumes a simple laminar pattern of basal ice flow. column with the point from which it is derived, which determines its isotopic composition. This has been done in Figure 5 for a series of columns along the Byrd Station flow line. We have ignored any strains within the ice. The important predictions are:

(a) Predictions of numerical $\delta^{18} \mathrm{O}$ values in basal ice and subglacial water.

(b) There will be an abrupt change in isotopic composition at the upper boundary of the regelation ice zone, to a lower $8^{18} \mathrm{O}$ value in normal glacier ice.

(c) There will be an upward increase in $8^{18} \mathrm{O}$ values in the regelation ice.

(d) At the upper end of the flow line, $\delta^{18} \mathrm{O}$ values in regelation ice will be higher than in overlying ice, but further down-glacier the lower part of the regelation ice zone will have lower $8^{18} \mathrm{O}$ values than overlying ice.

(e) $8^{18} \mathrm{O}$ values for subglacial water will become progressively smaller than normal ice values as we move down the flow line.

To what extent are these predictions borne out in practice?

We find that $\delta^{18} \mathrm{O}$ values in subglacial water at Byrd Station are lower than in the overlying ice (Fig. 3a). Theory predicts that the difference between subglacial melt water and the basal part of normal ice at Byrd Station should be $5.4^{0} \%$. In practice we find a difference of $5.3^{\circ} \%$.

Theory predicts that the differences between $\delta^{18} \mathrm{O}$ values for subglacial water and the glacier sole with which it is in contact should be $3.0^{\circ} \% 0$. In practice we find a difference of about $2.9^{\circ} \% 0$.

Assuming the regelation ice to have been produced from ice with the same isotopic composition as the lowest normal glacier ice, predicted maximum and minimum isotopic values are -29.1 and -34.3 , respectively, compared with measured values of -28.6 and -36 , and a predicted mean of -31.88 compared with -32.95 .

Apart from the last, we are impressed by these similarities.

However, the patterns referred to in predictions (b) $-(d)$ above are not borne nut in practice.

Observations on modern glaciers frequently show complex patterns of strain in basal ice. Folding and narrow zones of high shear strain are particularly common in basal ice and might be expected to complicate isotopic profiles (Boulton, 1983). However, although we might expect such processes to disturb the patterns shown in Figure 5a, the range of isotopic values which we predict should be preserved. Thus, the highest predicted $\delta^{18} \mathrm{O}$ value, at the top of the regelation zone if the sequence were undisturbed, and the lowest predicted value, at the glacier sole, should be found in the isotopic sequence of Byrd Station, notwithstanding any complex deformation. Figure 5 predicts a maximum range of $8^{18} \mathrm{O}$ values of $5.2^{0} \%$ and a mean of $-31.9^{0} \%$. The measured range is $7.5^{\circ} / 00$ with a mean of $-32.95^{\circ} \% 0$

The major quantitative discrepancy arises from a series of horizons which are isotopically lighter than we expect, several of which lie outside the theoretically expected range. Whereas complex patterns of deformation may change the mean by changing the relative proportions of isotopically different ice in a particular vertical column, it cannot explain values which lie outside the expected range. To do this, we must assume that some of the ice from which the regelation ice was formed was isotopically lighter than the lowest normal glacier ice at Byrd Station. The extreme value of $-36 \%$ in regelation ice would require a source at least as low as $-34^{0} / 00$.

The ice immediately above the basal regelation layer at Byrd Station has been estimated by Epstein and others (1970) to have formed between 70 and $100 \mathrm{ka}$ (Fig. 3c), and would thus belong to early glacial stages $5 a-d$ of the deep ocean record. If ice older than the basal normal glacier ice at Byrd Station were isotopically colder $\left(-34^{\circ} / 00\right)$, it could be interpreted as having accumulated on the glacier surface during stage 6 , the lowermost $2 \mathrm{~m}$ of normal ice with the 
highest isotopic values of about $-32 \%$ could represent the last interglacial (stage $5 e$ ), with the early glacial stage $(5 a-d)$ beginning with the ice about $8 \mathrm{~m}$ above the bed with isotopic values of $-34^{0} \%$.

We conclude that our numerical predictions are sufficiently good at Byrd Station to suggest that most of the simple assumptions underlying the theory are plausible. However, if the theory is to be applied at Byrd Station, we must relax the implicit assumption of a single pattern of strain in basal ice, and assume that the stratigraphy of basal ice is disturbed by complex patterns of folding. It is not difficult to imagine how a basal profile such as that at Byrd Station might have originated by folding.

The fact that complex isotopic patterns do not appear to extend upwards above the debris-rich regelation ice may be due to the role of these debris inhomogeneities in generating complex strain patterns.

\section{THE INFLUENCE OF COMPLEX DEFORMATION PATTERNS IN BASAL ICE}

Direct observations of patterns of folding and faulting in the basal parts of glaciers indicate that extremely complex patterns of deformation are common. It is also frequently found that complex patterns of deformation immediately above the glacier bed give way upwards to more uniform patterns reflecting simple shear strain (Fig. 6). It is as if a basal boundary layer of ice accommodates itself to the irregularity of the bed, allowing overlying ice to flow more smoothly over an "effective bed" of ice and substratum which together form a relatively smooth plane. This décollement plane often coincides with or is close to the upper surface of the basal ice carrying subglacially derived debris.

As at Byrd Station, the commonly accepted explanation of such subglacially derived debris is that it has been frozen in to the base of the glacier, and thus that the ice within which it occurs is regelation ice (Weertman, 1961; Kamb and LaChapelle, 1964; Boulton, 1970). The characteristics of the ice are well known. Strong vertical and horizontal changes of debris concentration occur within it and it contains many large clasts (Boulton, 1983). Compared with clean ice, we expect it to have a strongly anistropic rheology, as Hooke and others (1972) have shown that strain-rates for debris-rich ice are less than for clean ice under similar stress and temperature conditions, whilst some observations even suggest that very low concentrations might even lead to enhanced strain-rates.

We suggest that complex patterns of deformation result partly from complex patterns of stress orientation produced

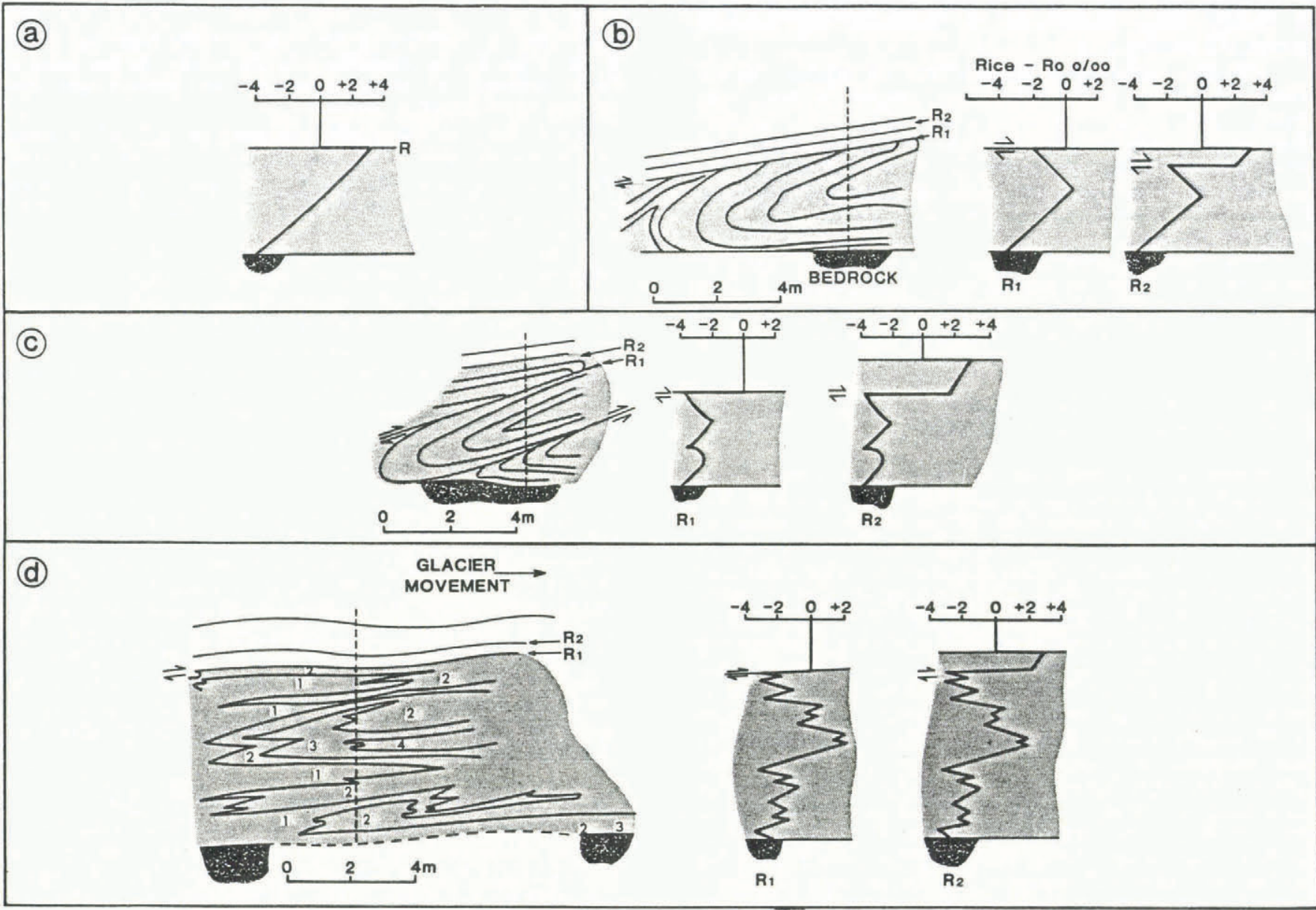

Fig. 6. The effect of complex patterns of basal flow on isotopic profiles. (b)-(d) show observed patterns of folding and faulting, often beneath a planar décollement surface, and the changes they might produce in an originally simple isotopic pattern.

(a) Isotopic pattern in basal regelation ice in which simple laminar flow has occurred (cf. Fig. $5 d)$.

(b) Pattern of basal folding beneath a sharp décollement in Sørbreen, Spitsbergen.

(c) Basal folding and faulting in Aavatsmarkbreen, Spitsbergen.

(d) Multiple folding in the basal ice of Lower Wright Glacier, Antarctica. Numbers identify different folded strata.

The effect of this folding on an assumed initial isotopic profile such as that in (a) is shown. The direction of displacement of the isotopic profile at the top of regelation ice (shaded) depends on whether the top of the regelation ice coincides with the décollement (position RI), or whether it lies above the décollement (position R2). Vertical dashed lines show the positions of hypothetical isotopic profiles in the folded ice. 
by flow over an irregular bed and partly from the strongly anisotropic strain response of debris-rich ice. We expect that the décollement separating a complexly deforming basal zone and an overlying zone of simple shear will frequently coincide with the top of the debris-rich regelation ice, or be near to it.

Figure 6 shows three examples of increasingly complex fold and fault structures observed in basal parts of modern glaciers which reflect increasingly complex net strain patterns. The commonest fold style is a shear fold in which anticlinal closures are highly attenuated, and synclinal closures are best preserved, though multiple folding events may be superimposed. We show the way in which the net strain indicated by these patterns might produce complex isotopic patterns in a pre-existing isotopic profile resulting from the simple regelation process modelled in Figure 5. Where the downward passage from normal glacier ice to regelation ice is above the major tectonic décollement, this passage will be marked by a sharp increase in $\delta$ values of about $3^{0} / 00$ (cases marked R2 in Figure 6), although complex isotopic patterns will occur beneath the underlying décollement. Where the regelation ice is entirely below the décollement plane, the tendency for synclinal fold closures to dominate beneath this plane will emplace some of the lower horizons of regelation ice into a position directly beneath it (Fig. 6). Thus, an isotopic profile through the décollement will tend to show a sharp reduction in $\delta$ values in passing from normal ice to regelation ice (patterns marked $\mathrm{R} 1$ in Figure 6).

Although coincidental juxtaposition of similar isotopic values might fail to show a sharp isotopic change when passing into basal regelation ice when the tectonic décollement coincides with the top of the regelation ice (probably its mean position), a sharp deflection will normally be expected. This should coincide with the occurrence of mineral and rock debris frozen on during the regelation process.

It is also important to stress that the upper limit of debris derived from the glacier bed marks the lower limit of the ice whose isotopic composition reflects in some simple way past atmospheric conditions on the ice-sheet surface.

\section{APPLICATION OF THE THEORY TO OTHER ISOTOPIC PROFILES FROM POLAR GLACIERS}

Irrespective of any deformation patterns which might complicate the isotopic profile expected from regelation in a simple planar flow regime (Fig. 4), an important feature of the fractionation process is likely to survive. This is the large range of isotopic values produced by completed progressive fractionation, which is thus likely to yield a major positive or negative spike, or both, in the basal isotopic profile. (As the final, most negative, regelation fractions will be contained in relatively thin ice increments, coarse sampling may underestimate the true isotopic range.) Major shifts and spikes in basal isotopic profiles from ice sheets are commonly found. They occur in the Devon Island Ice Cap (Paterson and others, 1977; Fisher and others, 1983; Robin, 1983), at Camp Century and Dye 3 in Greenland (Dansgaard and others, 1982), and in Terre Adélie (Lorius and Merlivat, 1977) and Byrd Station (Gow and others, 1979) in Antarctica. We have argued that our theory can explain the basal part of the Byrd Station isotopic profile and, although this may not be true at other sites, the possibility should at least be considered.

Dansgaard and others (1982) have described isotopic profiles from the lowermost few metres of the Greenland ice sheet at Camp Century (in north-west Greenland) and Dye 3 (in southern Greenland). Debris derived from the subglacial bed occurs in the lowermost few metres at both sites (Fig. 7). At neither of them does basal freezing-on currently occur, although Herron and Langway (1979) have suggested that the basal, debris-bearing ice at Camp Century is regelation ice which formed at some time in the past. In both cases, the isotopic profile shows a strong shift of the order of $3 \%$ at the interface between relatively clean ice and the basal debris-bearing ice. In the case of Dye 3, values increase, whilst for Camp Century they decrease.

The coincidence of an isotopic shift with the change

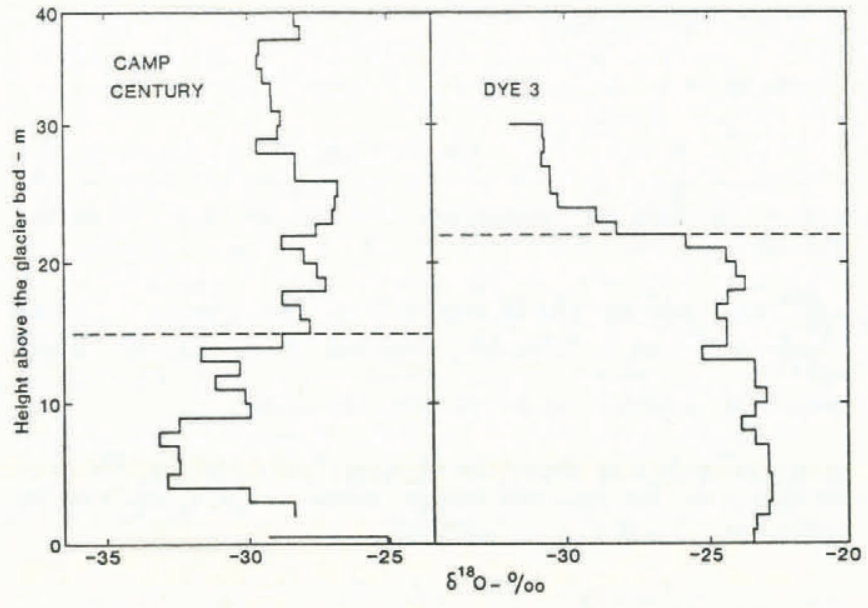

Fig. 7. Basal isotopic profiles from Camp Century and Dye 3 on the Greenland ice sheet (from Dansgaard and others 1982; the basal value at Camp Century is a personal communication from Dansgaard, 1982). Horizontal dashed lines show the upper limit of basally derived debris.

from clean to debris-rich ice is compatible with our model if the basal ice is regelation ice, an origin, in the case of Camp Century at least, supported by independent data (Herron and Langway, 1979).

According to our model, the positive shift of $\delta$ values at the top of debris-rich ice at Dye 3 would reflect an untectonized contact between normal glacier ice and regelation ice, while the positive shift at Camp Century would reflect a tectonized contact.

Again, it must be stressed that simple climatic or stratigraphical interpretations of isotopic profiles in basal ice of the type made by Dansgaard and others (1982) are invalid where this ice contains subglacially derived debris, particularly if this is regelation ice.

The theory developed above applies to a large-scale closed system in a steady state in which net basal melting in one part of the glacier is balanced by net basal freezing in another part. It can clearly be extended in a simple way to several partially open systems:

(a) Where only part of the total subglacial melt-water discharge is consumed by regelation ice and the rest is discharged from the glacier snout or into a further zone of melting. In this case, the glacier terminus or the new melting zone would be represented by a point in Figure 2 to the right of the left-hand margin of the graphs. The composition of last-formed regelation ice and the melt-water discharge would be given by corresponding points on the curves. A bore hole which reaches a glacier bed in the regelation zone will also miss the last, isotopically light, regelation fractions.

(b) (i) Where surface melt water reaches the glacier sole to mix with subglacially derived melt water. This mixing could occur in a general zone of basal melting, from which the mixed melt water would flow on into a closed freezing zone and undergo progressive fractionation as shown in Figure 2.

(ii) Alternatively, surface melt water could also reach the glacier sole in a general zone of freezing. Net freezing-on occurs at the base of a glacier where there is strong surface cooling and a strong internal temperature gradient which conducts away the latent heat produced by basal freezing. The upward decrease in temperature effectively seals the glacier bed against penetration of surface melt water along relatively narrow, easily frozen conduits. Thus, unless there are large open water conduits to the glacier bed, most subglacial water will be basally produced. However, if major crevasses are open to the bed, surface melt water may penetrate rapidly, import sufficient heat to 


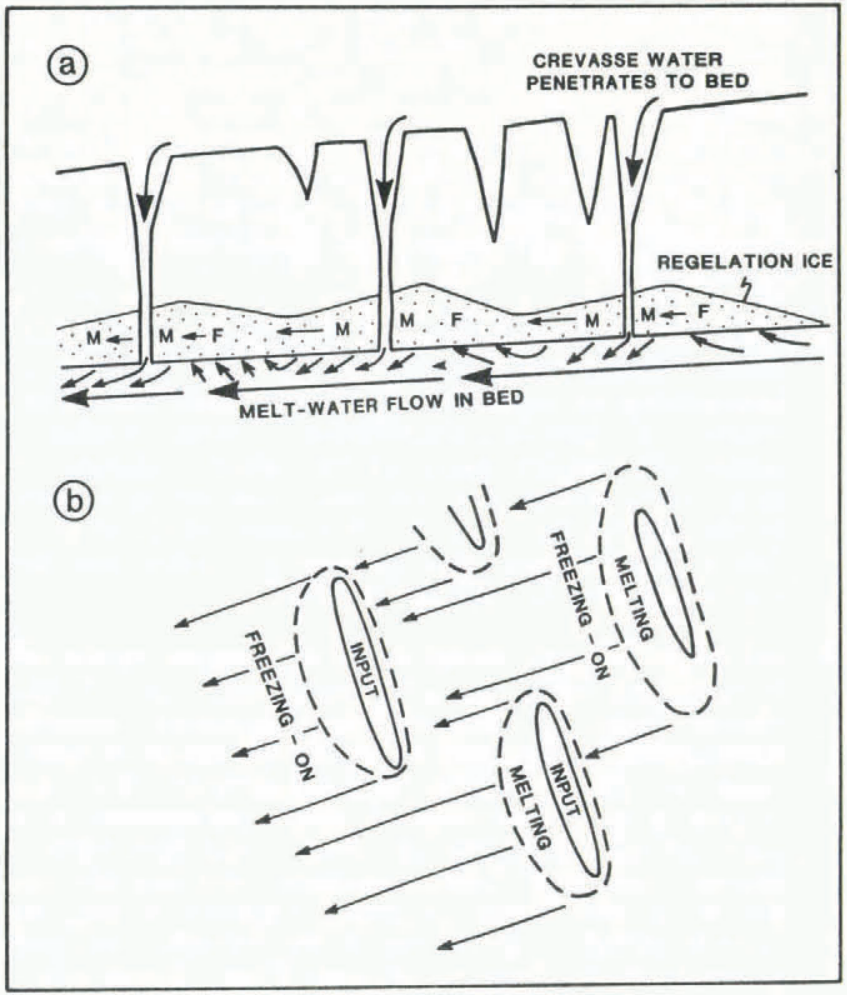

Fig. 8. Isotopic profiles in the basal part of Matanuska Glacier (from Lawson and Kulla, 1978). The data from the few transects reported by them are related to datum points at the boundary of diffused and dispersed ice facies, and the top of the stratified ice facies (debris-rich regelation ice).

prevent freezing, and warm the glacier bed in broad zones around them (Fig. 8). In this case, local water inputs would be frozen to the glacier bed near to the input zones.

(c) Loss of basal melt water from the melting/regelation system into a subglacial aquifer. If this occurred in the zone of melting, or just into the zone of regelation, its effect would largely be to diminish the thickness of the regelation ice which would form from any residual water. If it occurred towards the distal extremity of the regelation zone, the effect would be to lose the last-formed isotopically light regelation fraction.

Lawson (1979) published $8^{18} \mathrm{O}$ values from profiles through the basal part of Matanuska Glacier in southern Alaska, where he believed normal glacier ice overlay up to $15 \mathrm{~m}$ of regelation ice. He suggested that this latter was derived by freezing-on of subglacially flowing melt water, and that as the glacier was crevassed in the thin terminal zone that much of the frozen-on melt water was derived from local surface sources. His transects (Fig. 9) all show higher $\delta^{18} \mathrm{O}$ values in the presumed regelation ice than in the overlying normal ice. His regelation zone comprised a stratified ice/debris facies, and normal ice was described as a diffused ice/debris facies, with a thin transitional dispersed facies between them.

The sudden increase in $\delta^{18} \mathrm{O}$ across the contact between diffused/dispersed facies and stratified facies supports the idea that the latter is regelation ice and that isotopic fractionation occurred during its formation, as suggested by Lawson (1979) and Lawson and Kulla (1978).

How could this general model of the progressive fractionation by continuous freezing of water from a single subglacial source (Fig. 2) apply to Matanuska Glacier? Three explanations, based on those set out above, seem possible.

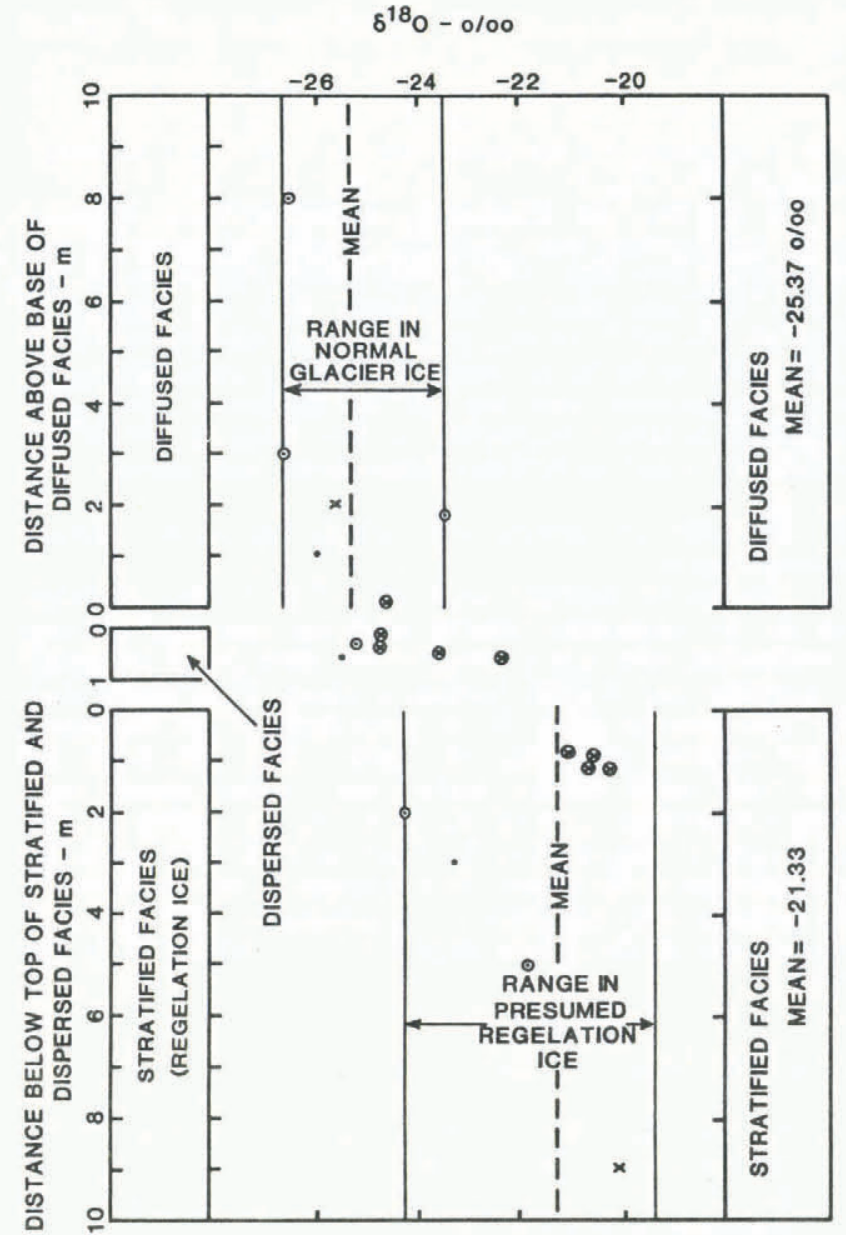

TRANSECT $4^{-} \bullet$ TRANSECT $3^{-x}$ TRANSECT $2^{-} \bullet$ TRANSECT $1^{-\bullet}$

Fig. 9. $a$ and b. Postulated zones of melting and refreezing produced when crevasses allow melt water to penetrate to the bed of otherwise cold glaciers.

(i) Closed system with a single subglacial water source

Assume that melt water derived from zone $\mathrm{B}-\mathrm{C}$ (Fig. 1) progressively freezes to the glacier sole in zone C-D. Let us assume that complex deformation patterns have destroyed the original isotopic pattern in the basal debris-rich zone (Lawson (1979, fig. 5) showed complex folding in this zone which contrasts with overlying zones), but that sampling has produced a reasonable estimate of the true isotopic variation. The range of variation is $4.5 \%$. The isotopically heavy ice will have formed at the up-glacier extremity of the freezing-on zone and the isotopically light ice either at the sampling site, if the freezing-on zone extends to the site, or at its down-glacier extremity if it does not. From Figure 2, an isotopic range of $4.5 \%$ will be achieved when $Q / Q_{0}=0.22$, that is when $78 \%$ of the original melt water has been frozen to the glacier sole and the rest still flows subglacially beneath the site. Thus, this could not be a closed system, but would be analogous to variant (a) above, being open at the distal extremity. For a maximum $\delta$ value in the regelation ice of $-19.7^{\circ} / 00$, which according to this model would be produced at the up-glacier extremity of the freezing-on zone, the basal ice from which the melt water was derived would have had a value of $-16.7^{0} / 00$. However, the basal $10 \mathrm{~m}$ of normal glacier ice at the sampling site has a mean $\delta$ value of $-25.37^{\circ} \%$, which would need to have been underlain by isotopically heavier ice in the melting zone if this model is correct. However, as lower ice is derived from a higher elevation, we normally expect a reduction in $\delta$ values towards the glacier bed, which does indeed occur in the diffused facies of Matanuska Glacier. We thus reject this explanation. 


\section{(ii) Partially open system with surface ingress in the melting} zone

In this model we allow surface water to reach the glacier sole in a zone of basal melting ( $\mathrm{B}-\mathrm{C}$; Fig. 1), to mix with subglacially melted water, and to flow into a freezingon zone (C-D; Fig. 1).

In this case, the fractionation model would be the same as in the previous case, with the sample site lying in the freezing-on zone after $78 \%$ of melt water had frozen to the glacier sole and with a water input into the freezing-on zone of $\delta=-16.7$. In this case, however, the production of such water would be envisaged as resulting from melting of local precipitation and old ice at surface (Lawson has suggested surface precipitation in the range $\delta=3-14^{0} / 00$ ) which mixes with isotopically lighter basal melt water.

(iii) Partially open system with multiple sources in a deeply crevassed glacier

The limited isotopic range of $4.5^{\circ} / 00$ in the regelation ice at the Matanuska Glacier sampling site suggests that fractionation does not progress to its limit when regelation is complete and a final fraction is about $9 \%$ lighter than the first fraction (Fig. 2). A great deal of the variability might reflect variability of input, and the mean of $\delta=-16.7$ could reflect surface melt water mixed from fresh precipitation and old ice in a situation similar to that of variant (a) above (Fig. 8). Thus, although hypothesis (c) and hypothesis (b) cannot be distinguished on the basis of the isotopic data, Lawson's (1979) comments about the crevassed state of the glacier suggest that hypothesis (c) is the better.

\section{SUMMARY AND CONCLUSIONS}

(1) In cold ice sheets with a thermally complex basal boundary, refreezing of basal melt water occurs in a large-scale closed system and frequently produces thick sequences of regelation ice.

(2) Whereas melt water preserves the isotopic ratios of the parent ice, regelation ice formed from an excess of melt water is preferentially enriched in the heavy isotopes ${ }^{2} \mathrm{H}$ and ${ }^{18} \mathrm{O}$. A theory of progressive fractionation of melt water and the regelation ice formed from it is developed for a subglacial zone in which basal freezing-on progressively exhausts melt water from an adjacent zone of melting.

(3) The theory yields predictions about the mean isotopic ratios in regelation ice, the range of these ratios, and the vertical trend, together with the composition of subglacial melt water.

(4) The theory is tested by using Budd and others' (1970) temperature and discharge model along the West Antarctic ice sheet flow line through Byrd Station. The isotopic composition of basal ice in the Byrd Station bore-hole core is predicted together with the composition of basal melt water. All the isotopic characteristics of the basal regelation ice and melt water are predicted successfully apart from the precise nature of the vertical isotopic trend in the ice. We suggest that complex patterns of deformation which are likely to occur in basal debris-rich ice have re-organized isotopic trends.

(5) We also suggest that the isotopic composition of normal glacier ice destroyed in a zone of melting can be reconstructed from the composition of the regelation ice formed from its melt water. We suggest that ice destroyed by melting beneath the level of the lowest "normal" ice at Byrd Station had a $\delta^{18} \mathrm{O}$ ratio $2.0^{0} / 00$ lighter than the latter and that it may reflect the end of the penultimate glacial period.

(6) In ideal circumstances, the theory can be used to explain the significance of isotopic profiles through the basal horizons in glaciers which behave as closed systems or partially open sytems and in which net basal freezing-on is believed to have occurred. It can also be used as a means of deducing some characteristics of subglacial hydrology. In one case, Matanuska Glacier, Alaska, we deduce from the isotopic data that there is a strong influx of surface melt water which produces a relatively constant isotopic ratio within the subglacial reservoir from which regelation ice forms. This is thus an open system and there is no significant progressive fractionation.

(7) It is an important hypothesis in glacial geology that much subglacially derived debris in glaciers is incorporated by regelation of subglacial melt water. Our theory of isotopic fractionation during regelation successfully predicts many of the isotopic changes in basal debris-bearing ice, and thus gives strong support to the concept that regelation is a major agent of basal debris incorporation, and provides a further tool by which regelation ice can be identified.

(8) Although in ideal circumstances a complete record of fractionation might occur in basal ice, flow of the glacier over an irregular bed produces complex deformation in this basal ice which we expect in many cases to disrupt simple isotopic patterns. However, certain styles of deformation seem characteristic and some general conclusions are drawn about their effects. Heavily deformed and completely fractionated ice should at least retain an abrupt negative or positive isotopic deflection at the top of the regelation ice, and a range of $\delta$ values of at least $9 \%$, though other trends may be obliterated by deformation.

\section{REFERENCES}

Boulton, G.S. 1970. On the origin and transport of englacial debris in Svalbard glaciers. Journal of Glaciology, Vol. 9, No. 56 , p. $213-29$.

Boulton, G.S. 1972. The role of thermal régime in glacial sedimentation. (In Price, R.J., and Sugden, D.E., comps. Polar geomorphology. London, Institute of British Geographers, p. 1-19. (Special Publication No. 4.))

Boulton, G.S. 1983. Debris and isotopic sequences in the basal layers of polar ice sheets. (In Robin, G. de Q., ed. The climatic record in polar ice sheets. Cambridge, Cambridge University Press, p. 83-89.)

Budd, W., and others. 1970. The extent of basal melting in Antarctica, by W. Budd, D. Jenssen, and U. Radok. Polarforschung, Bd. 6, Jahrg. 39, Nr. 1, 1969, p. 293-306.

Dansgaard, W., and others. 1973. Stable isotope glaciology, by W. Dansgaard, S.J. Johnsen, H.B. Clausen, and N. Gundestrup. Meddelelser om Grønland, Bd. 197, Nr. 2.

Dansgaard, W., and others. 1982. A new Greenland deep ice core record, by W. Dansgaard, H.B. Clausen, N. Gundestrup, and N. Reeh. Science, Vol. 218, No. 4579, p. $1273-77$.

Epstein, S., and others. 1970. Antarctic ice sheet: stable isotope analyses of Byrd Station cores and interhemispheric climatic implications, by S. Epstein, R.P. Sharp, and A.J. Gow. Science, Vol. 168, No. 3939, p. 1570-72.

Fisher, D.A., and others. 1983. Effect of wind scouring on climatic records from ice-core oxygen-isotope profiles, by D.A. Fisher, R.M. Koerner, W.S.B. Paterson, W. Dansgaard, N. Gundestrup, and N. Reeh. Nature, Vol. 301, No. 5897, p. 205-09.

Gow, A.J. 1970. Preliminary results of studies of ice cores from the $2164 \mathrm{~m}$ deep drill hole, Byrd Station, Antarctica. [Union Géodésique et Géophysique Internationale. Association Internationale d'Hydrologie Scientifique.] [International Council of Scientific Unions. Scientific Committee on Antarctic Research. International Association of Scientific Hydrology. Commission of Snow and Ice.] International Symposium on Antarctic Glaciological Exploration (ISAGE), Hanover, New Hampshire, U.S.A., 3-7 September 1968, p. 78-90. [(Publication No. 86 [de l'Association Internationale d'Hydrologie Scientifique].)] 
Gow, A.J., and others. 1979. On the origin of stratified debris in ice cores from the bottom of the Antarctic ice sheet, by A.J. Gow, S. Epstein, and W. Sheehy. Journal of Glaciology, Vol. 23, No. 89, p. 185-92.

Herron, S., and Langway, C.C., jr. 1979. The debris-laden ice at the bottom of the Greenland ice sheet. Journal of Glaciology, Vol. 23, No. 89, p. 193-207.

Hooke, R.L., and others. 1972. Creep of ice containing dispersed fine sand, by R.L. Hooke, B.B. Dahlin, and M.T. Kauper. Journal of Glaciology, Vol. 11, No. 63, p. $327-36$.

Jouzel, J., and Souchez, R.A. 1982. Melting-refreezing at the glacier sole and the isotopic composition of the ice. Journal of Glaciology, Vol. 28, No. 98, p. 35-42.

Kamb, W.B., and LaChapelle, E.R. 1964. Direct observation of the mechanism of glacier sliding over bedrock. Journal of Glaciology, Vol. 5, No. 38, p. 159-72.

Lawson, D.E. 1979. Sedimentological analysis of the western terminus region of the Matanuska Glacier, Alaska. CRREL Report 79-9.

Lawson, D.E., and Kulla, J.B. 1978. An oxygen isotope investigation of the origin of the basal zone of the Matanuska Glacier, Alaska. Journal of Glaciology, Vol. 86,
Lorius, C., and Merlivat, L. 1977. Distribution of mean surface stable isotopes in East Antarctica: observed changes with depth in the coastal area. [Union Géodésique et Géophysique Internationale. Association Internationale des Sciences Hydrologiques. Commission des Neiges et Glaces.] Symposium. Isotopes et impuretés dans les neiges et glaces. Actes du colloque de Grenoble, aout/septembre 1975 , p. 127-37. (IAHS-AISH Publication No. 118.)

O'Neill, J.R. 1976. Hydrogen and oxygen isotopic fractionation between ice and water. Journal of Physical Chemistry, Vol. 72, No. 10, p. 3683-84.

Paterson, W.S.B., and others. 1977. An oxygen-isotope climate record from the Devon Island ice cap, Arctic Canada, by W.S.B. Paterson [and 7 others]. Nature, Vol. 266, No. 5602, p. 508-11.

Robin, G. de Q., ed. 1983. The climatic record in polar ice sheets. Cambridge, Cambridge University Press.

Weertman, J. 1961. Mechanism for the formation of inner moraines found near the edge of cold ice caps and ice sheets. Journal of Glaciology, Vol. 3, No. 30, p. 